\title{
Diversity loss in grasslands due to the increasing dominance of alien and native competitive herbs
}

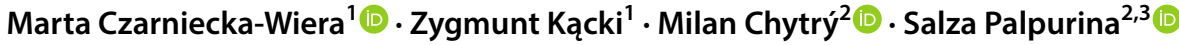

Received: 11 December 2017 / Revised: 11 April 2019 / Accepted: 6 June 2019 / Published online: 17 June 2019

(c) The Author(s) 2019

\begin{abstract}
The increasing dominance of competitive plant species may reduce species richness of plant communities. Yet, species richness may depend on spatial scale and the alien versus native status of the dominant species. To explore the dominance effects of alien versus native species on species richness, we sampled semi-natural grasslands in southwestern Poland. We established $100 \mathrm{~m}^{2}$ squares at different grassland sites, and in two opposite corners we placed two series of five nested plots $\left(0.001,0.01,0.1,1\right.$ and $\left.10 \mathrm{~m}^{2}\right)$, in which we recorded all vascular plant species. Next, we selected squares with a strongly dominant plant in one corner (high-dominance series) and with no strong dominant in the opposite corner (low-dominance series). The number of species per plot and the slopes of the species-area curves fitted to each nested-plot series were used to assess whether the alien vs. native status of the dominant species influences species-richness pattern across scales. We found a significantly lower number of species in the high-dominance series than in the low-dominance series, regardless of the alien versus native status of the dominant species. The slopes of the species-area curves indicated that the rate of species accumulation with increasing area was faster in the high-dominance series than in the low-dominance series; however, this pattern did not depend on the alien vs. native status of the dominants. Our study confirms that increasing dominance is linked to a decline in species richness, but reveals that alien dominants do not have a stronger impact than native dominants.
\end{abstract}

Keywords Competitive exclusion · Dominance $\cdot$ Plant invasions $\cdot$ Species-area relationship $\cdot$ Species richness $\cdot$ Temperate grasslands

Communicated by Daniel Sanchez Mata.

This article belongs to the Topical Collection: Invasive species.

Marta Czarniecka-Wiera

m.czarniecka86@gmail.com

1 Department of Vegetation Ecology, Botanical Garden, University of Wroclaw, S. Przybyszewskiego 63, 51-148 Wroclaw, Poland

2 Department of Botany and Zoology, Masaryk University, Kotlářská 2, 61137 Brno, Czech Republic

3 Institute of Biodiversity and Ecosystem Research, Bulgarian Academy of Sciences, Acad. G. Bonchev bl. 23, 1113 Sofia, Bulgaria 


\section{Introduction}

Semi-natural grasslands are important habitats for biodiversity conservation in European agricultural landscapes (Duelli and Obrist 2003; Tscharntke et al. 2005; Bonari et al. 2017). For centuries, these habitats have been used primarily for animal husbandry; however, this function has recently become less important due to decreasing livestock production (MacDonald et al. 2000; Poschlod et al. 2005; Wehn et al. 2017). As a consequence, many seminatural grasslands have been abandoned, afforested or converted into arable land or intensively managed grasslands (Falcucci et al. 2007; Prévosto et al. 2011). Changes in land use and in the management of semi-natural grasslands have led to the encroachment of trees and shrubs and to the expansion of alien or native competitors, which tend to dominate ecosystems (Hansson and Fogelfors 2000; Young et al. 2005).

Several studies have suggested that alien species invasions cause a decline in species richness (henceforth SR) of native plant communities (Parker et al. 1999; Byers et al. 2002; Hejda et al. 2009). This phenomenon is linked to the ability of alien species to become dominant in a plant community outside its native range and to locally replace native species (Pyšek and Pyšek 1995; Hejda and Pyšek 2006; Chmura et al. 2015). The evolution of increased competitive ability (EICA hypothesis; Callaway and Ridenour 2004) suggests that once separated from their natural enemies, alien species evolve to use more resources to develop competitive traits, e.g. larger size and increased fecundity. However, the relative abundance of native species can also increase in the changing environment. For example, after cessation of mowing and grazing in grasslands, species which represented a low proportion of the biomass of the managed grasslands can expand and attain dominance, resulting in a decrease in community SR (Falińska 1991). Examples of native European grassland plants that are becoming dominant with negative effects on SR include Brachypodium pinnatum in semi-dry grasslands (Bobbink et al. 1987), Molinia caerulea in wet meadows (Lepš 2004), Calamagrostis villosa in acidic sub-alpine grasslands (Hejcman et al. 2009) and Calamagrostis epigejos or Stipa pulcherrima in steppe grasslands (Házi et al. 2011; Ruprecht et al. 2016). It is not fully understood whether dominant alien plants species have a stronger impact on SR than dominant native plant species.

The effect of dominant species on SR depends on the sampling scale because species interactions tend to be intense within small areas, but weakening in larger areas where environmental heterogeneity tends to separate different species in space, thus reducing direct contact between plant individuals (Tilman and Pacala 1993). This scale-dependent effect is observable in studies on the impact of alien species' dominance on biodiversity: fine-scale studies more often suggest that invasive species are a threat to biodiversity (Gerber et al. 2008; Vilà et al. 2011), whereas coarse-scale studies tend to report a negligible impact (Planty-Tabacchi et al. 1996; Maskell et al. 2006). Powell et al. (2013) related this scaledependent effect of invasive species on SR to the species-area relationship (SAR). They sampled paired forest plots with and without invasive species and found that the decline in the number of species at the invaded sites, compared with that at non-invaded sites, was larger in smaller plots than in larger plots. However, many studies have highlighted that the SAR depends on the plant community type (Crawley and Harral 2001; Drakare et al. 2006; Dolnik and Breuer 2008). It is, therefore, unclear whether the pattern observed by Powell et al. (2013) is valid in other community types, such as grasslands.

In the present study, we compare the effects of dominant species, either alien or native, on SR of semi-natural grasslands to answer the following questions: (1) Does a decline in SR depend on the presence of a single strong dominant species in the plant community? If 
so, does this decline depend on (2) spatial scale and (3) the alien versus native origin of the dominant plant species?

\section{Materials and methods}

\section{Study area}

The study area is located in the Sudetes Mountains in southwestern Poland $\left(50^{\circ} 0^{\prime}-50^{\circ} 10^{\prime} \mathrm{N}\right.$, $15^{\circ} 20^{\prime}-16^{\circ} 55^{\prime} \mathrm{E}, 3800 \mathrm{~km}^{2}, 290-841 \mathrm{~m}$ a.s.l.; Fig. 1). The mean annual temperature ranges from 5 to $8{ }^{\circ} \mathrm{C}$ and the annual precipitation from 490 to $650 \mathrm{~mm}$ (Woś 1999). The bedrock consists of acidic and poorly weathered magmatic and metamorphic rocks (Walczak 1968). The vegetation studied includes semi-natural meadows belonging mainly to the phytosociological alliances Arrhenatherion and Polygono-Trisetion (Kącki et al. 2013). Since the 1980s, large areas of meadows in the Sudetes have been abandoned and subsequently overgrown by competitive herbaceous plant species, including some aliens (Biała and Żyszkowska 2004).

\section{Sampling design}

We sampled grasslands across the Sudetes from 2012 to 2014. The sampling sites were selected randomly within grassland areas using digital maps provided by the Institute of Technology and Life Sciences in Falenty, Poland. The maps included Digital Terrain Model (with elevation, slope and aspect), land cover and soil types (Nadolna and Żyszkowska 2011). Using ArcGIS 9.3, we overlaid the Sudetes with a $10 \times 10-\mathrm{km}$ grid and selected grid cells with $>25 \%$ grassland cover. In each selected grid cell, we placed five random points in grassland areas and created a circular buffer zone of $250 \mathrm{~m}$ radius

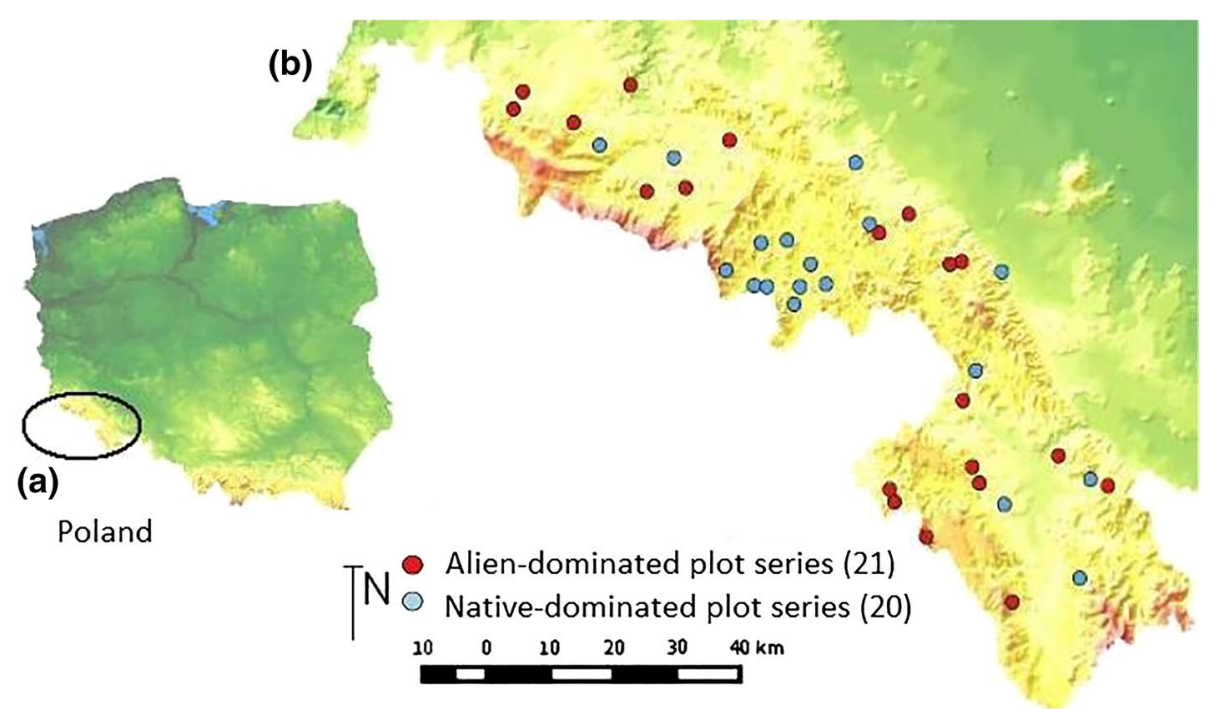

Fig. 1 Location of the 41 sampled paired nested-plot series in the Polish part of the Sudetes Mountains (http://www.codgik.gov.pl/index.php/darmowe-dane/nmt-100.html. Accessed 2nd Oct 2018) 
around each point. To avoid overlaps between the buffer zones, we ensured that the minimum distance between random points was $1 \mathrm{~km}$. During the field survey, within each buffer zone, we selected a single vegetation stand with an alien plant species that was as close as possible to the central point of its buffer zone. If no alien species were found within the buffer zone, a vegetation stand without alien species at the central point was selected. In each vegetation stand, we established a square of $100 \mathrm{~m}^{2}$ at a place that was as homogeneous as possible in terms of topography and vegetation physiognomy. Next, in two opposite corners of the $100 \mathrm{~m}^{2}$ square, we placed a series of five squared nested plots of increasing sizes (in $\mathrm{m}^{2}$ ) as follows: 0.001, 0.01, 0.1, 1 and 10 (Fig. 2; Dengler 2009). In each nested-plot series, the presence of shoots of all species of vascular plants was recorded. The percentage cover of each species was visually estimated in the largest nested plot $\left(10 \mathrm{~m}^{2}\right)$ of the series. The vegetation data are stored in the Polish Vegetation Database (Kącki and Śliwiński 2012).

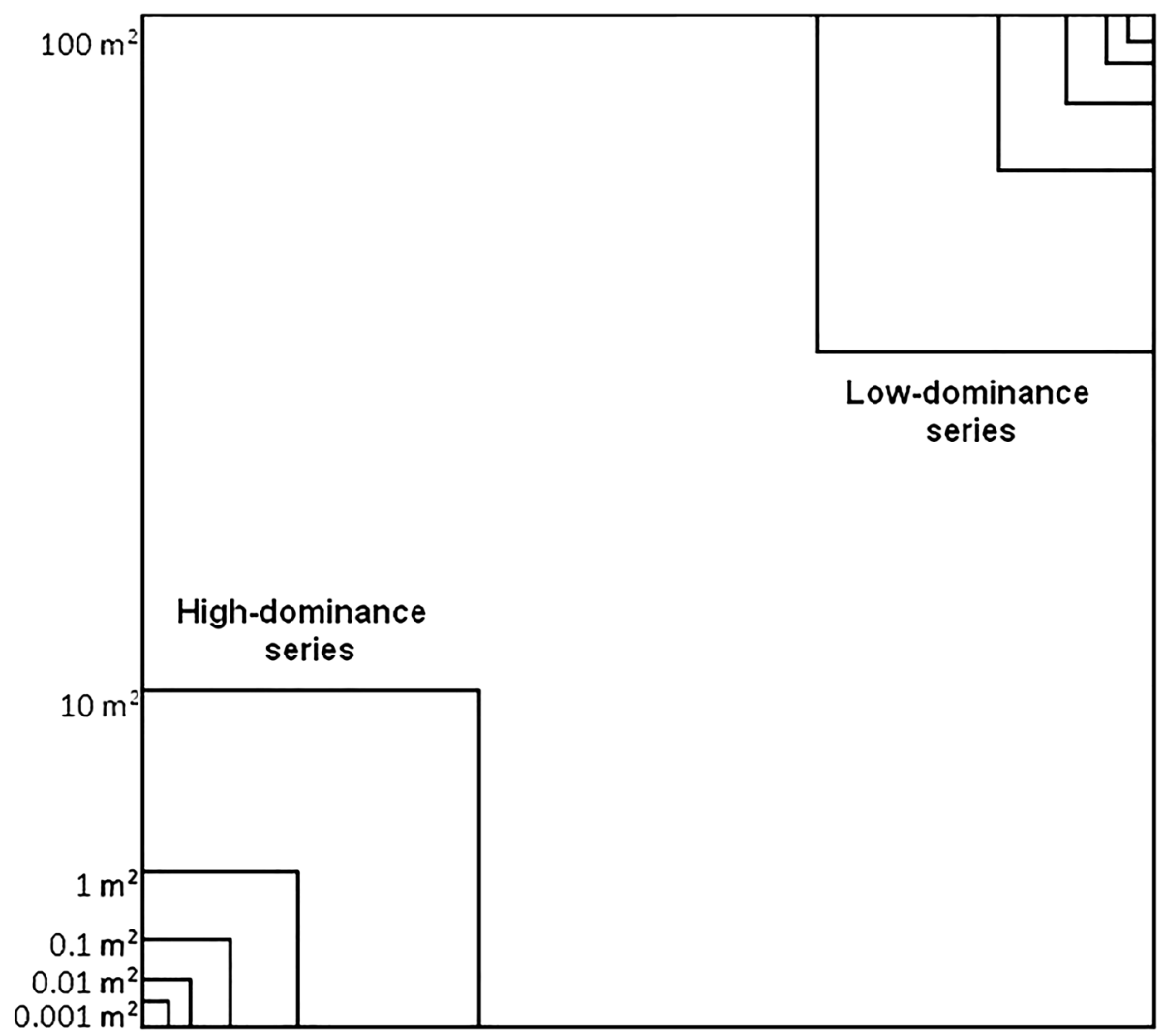

Fig. 2 Plot sampling design. Paired series of nested plots measuring between 0.001 and $10 \mathrm{~m}^{2}$ were arranged in two opposite corners of each $100 \mathrm{~m}^{2}$ square. The high-dominance (HD) series include plots in which the cover of the most abundant species was at least $20 \%$ higher than the cover of the most abundant species in the other (low-dominance, LD) series. Note that the plot size is not on a true scale 


\section{Dataset and statistical analyses}

We collected data from 198 squares of $100 \mathrm{~m}^{2}$, each with two nested-plot series located in two opposite corners of the square. For analyses, we selected a subset of those squares in which the cover of the most abundant species in the largest plot of the nestedplot series $\left(10 \mathrm{~m}^{2}\right)$ in one corner (high-dominance series, henceforth HD series) was at least $20 \%$ higher than the cover of the most abundant species in the largest plot of the series in the opposite corner (low-dominance series, henceforth LD series). However, to acknowledge the possible effects of varying threshold differences in cover, we tested their effects on SR and the rate of species accumulation with increasing area. We used eight thresholds from 10 to $70 \%$ (as we did not have plots with a larger difference in cover above $70 \%$ ) with 10 unit increments.

Application of this criterion resulted in the selection of 62 squares. These squares were further divided into the following subsets: (1) alien-dominated subset, in which the dominant species in the HD series was alien and there were no aliens in the LD series $(\mathrm{n}=21)$; (2) native-dominated subset, in which the dominant species in the HD series was native, and there were no aliens in the LD series $(n=20)$; (3) the dominant species in the HD series was native, but there were also aliens (not dominant) in the LD series $(n=21)$. We excluded the third subset from the analysis to avoid any influence of alien species in the LD series on SR. In our final selection of 41 squares (Fig. 1), the dominant alien species were Solidago gigantea, S. canadensis, Lupinus polyphyllus and Reynoutria sachalinensis, whereas the dominant native species were Carex brizoides, Agrostis capillaris, Festuca rubra, Galium mollugo s. 1., Lathyrus pratensis and Calamagrostis epigejos (Table 1). The species names are given following the Euro + Med PlantBase (http://www.emplantbase.org/home.html, Accessed 2nd Nov 2018).

As a measure of SR, we used the number of all vascular plant species per single nested plot. The dependence between dominance and SR was assessed by comparing SR between the HD and LD series using paired Student's $t$ test (after Bonferroni correction). The analyses were applied separately for each plot size across all pairs of nestedplot series regardless of the status of the dominant species $(n=5 \times 41)$ and separately for the alien-dominated and native-dominated subsets.

To assess the magnitude of the effect of dominant species on SR, we calculated standardised difference in SR between the high-dominance and low-dominance series $\left(\delta_{\mathrm{SR}}, \%\right)$ as follows: $\delta_{\mathrm{SR}}=\frac{\left(\mathrm{SR}_{\mathrm{HD}}-\mathrm{SR}_{\mathrm{LD}}\right)}{\mathrm{SR}_{\mathrm{LD}}} \times 100$, where $\mathrm{SR}$ is species richness, HD is the high-dominance series of nested plots and LD is the low-dominance series of nested plots. $\delta_{\mathrm{SR}}=0 \%$ means that there is no difference in terms of SR between the HD and LD series and $\delta_{\mathrm{SR}}=-50 \%$ means that the SR in the HD series is half of that in the LD series. We then used ANOVA (after Bonferroni correction) to test whether the mean $\delta_{\mathrm{SR}}$ differed between the alien-dominated and native-dominated subsets.

We used SAR to measure the rate of species accumulation with increasing area. SAR can be modelled using the power-law function $S=c A^{\mathrm{z}}$, where $S$ is the number of species and $A$ is the sampling area. The model parameters $c$ and $z$ express the expected mean SR per unit area and the rate of species accumulation with an increase in sampling area, respectively (Arrhenius 1921; Rosenzweig 1995; Dolnik and Breuer 2008). We used the power function in the 'mmSAR' package (Guilhaumon et al. 2010) to fit the power-law function to each nested-plot series. We then used paired $t$-tests to check whether the obtained $c$ - and $z$-values differed significantly between the paired HD and LD series across both subsets. 


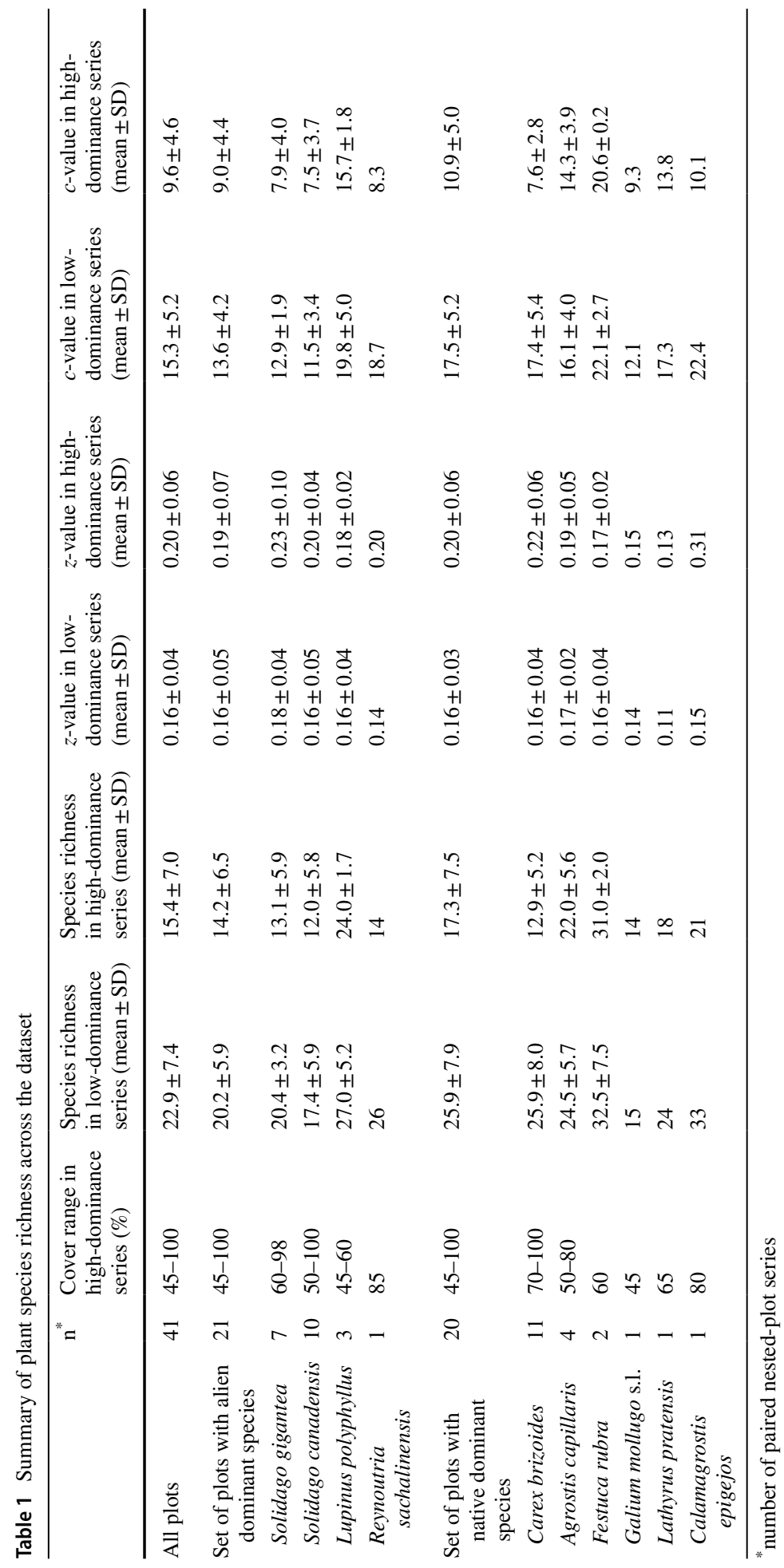


To test whether the magnitude of the dominance effect depends on the alien vs. native status of the dominant species, we calculated the difference in $c$ - and $z$-values between HD and LD series (i.e. $\delta_{\mathrm{c}}=\mathrm{c}_{\mathrm{HD}}-\mathrm{c}_{\mathrm{LD}}, \delta_{\mathrm{z}}=\mathrm{z}_{\mathrm{HD}}-\mathrm{z}_{\mathrm{LD}}$ ) and tested by means of ANOVA whether $\delta_{\mathrm{c}}$ and $\delta_{\mathrm{z}}$ differed between the alien- and the native-dominated subset.

\section{Results}

Paired $t$-test revealed that SR was significantly lower in the HD series than in the LD series (Fig. 3). This was valid for the entire dataset (Fig. 3a) and for the alien- or native-dominated subsets (Fig. 3b, c). The mean standardized difference in SR $\left(\delta_{\mathrm{SR}}\right)$ did not differ between the alien-dominated and native-dominated subsets (Fig. 4).

Paired $t$-tests revealed that $c$-values were significantly lower in the HD series than in the LD series, whereas $z$-values were significantly higher in the HD series than in the LD series. This means that the mean SR per unit area was lower for the HD series, but its increase with plot size was faster than in the LD series (Fig. 5). However, ANOVA tests for $c$ - and $z$-values showed no significant difference between the alien- and native-dominated subsets (Fig. 6).

Individual dominant plant species were found to have influenced SR and SAR parameters. The largest difference between the HD and LD series for SR as well as $c$ - and $z$-values of SAR were found for Solidago gigantea (alien), S. canadensis (alien) and Carex brizoides (native) and the lowest for Lupinus polyphyllus (alien) and Agrostis capillaris (native) (Table 1).

We found that larger threshold difference in cover for considering a species to be dominant corresponds to larger difference in SR as well as in $c$ - and $z$-values between the HD and LD series ("Appendix 1"). In other words, the larger the difference in cover between the most abundant species in one series and the most abundant species in the other series in a pair, the stronger is its effect on SR and species-accumulation rate.

\section{Discussion}

Dominance is one of the main factors that affect species coexistence in plant communities (Whittaker 1965; Hillebrand et al. 2008). In the present study, we asked whether the decline in SR depends on the presence of a strong dominant species in the plant community. We provided evidence that grassland plant communities with strongly dominant herbaceous species tend to be more species-poor than communities with less dominant species. The observed significant difference in SR can be explained by interspecific competitive interactions which lead to the dominance of a few or just one species in the community (Tilman and Pacala 1993). A decline in SR with increasing dominance was observed in many ecosystems, such as forests (de la Cretaz and Kelty 1999), open water (Zehnsdorf et al. 2015), and dry grasslands (Dostálek and Frantík 2012), suggesting that it is a common phenomenon.

We also asked whether the magnitude of the decline in SR depends on the spatial scale. We found that the dominance of competitive plants changed the SR pattern in the studied grasslands. We also found that the rate of species accumulation with increasing plot size (as estimated by the $z$-value of the SAR) was higher in the high dominance grasslands than in the low dominance grasslands, suggesting a stronger negative 
Fig. 3 Species richness (the number of vascular plant species per plot; SR) compared between the high-dominance (HD, grey) and low-dominance (LD, white) series of all paired nested plots, $n=41$ (a), for the alien-dominated subset, $n=21(\mathbf{b})$, and for the native-dominated subset, $n=20$ (c). The boxes represent interquartile ranges, the horizontal lines within boxes represent medians, the whiskers represent outliers, and the white and grey points represent extreme values. Differences in SR between the HD and LD series were tested separately for each plot size using Student's $t$-test for paired samples (after Bonferroni correction): $* \mathrm{p}<0.05, * * \mathrm{p}<0.01$ and $* * * \mathrm{p}<0.001$ (a) All nested-plot series

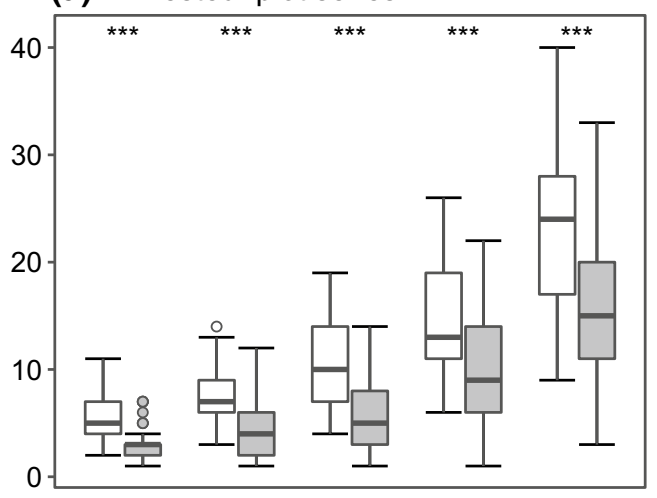

(b) Alien-dominated nested-plot series

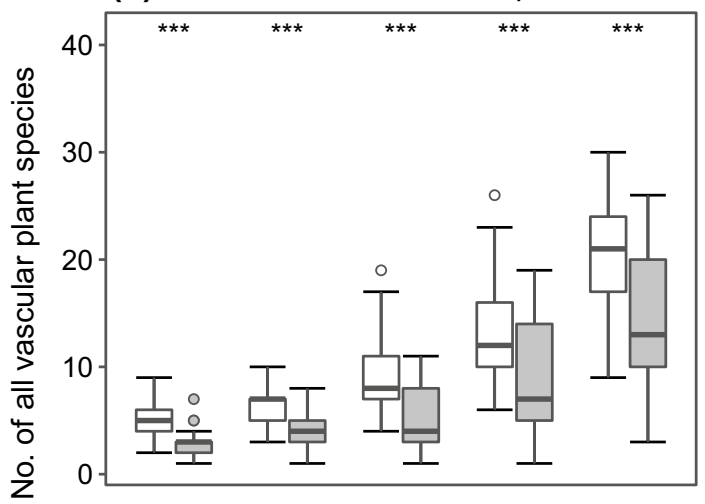

(c) Native-dominated nested-plot series

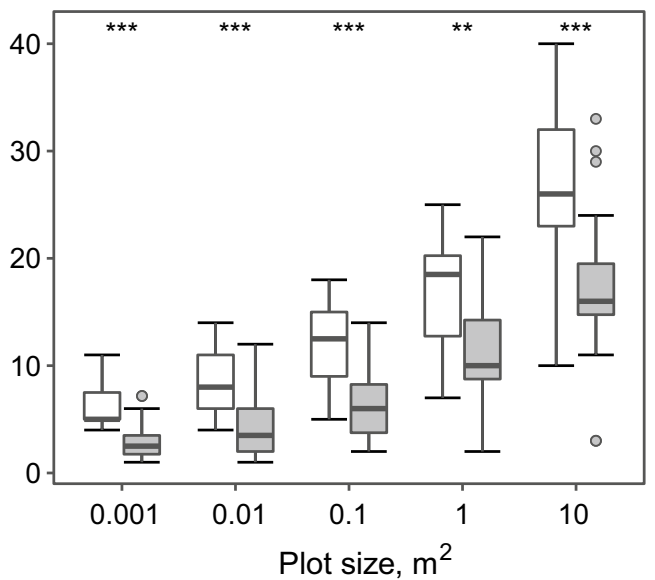

effect of dominance on SR in small areas. In small areas, the competition among species is stronger, leading to the extinction of less competitive species, whereas on a broader scale, the impact of the dominant competitors is less pronounced because there are more 


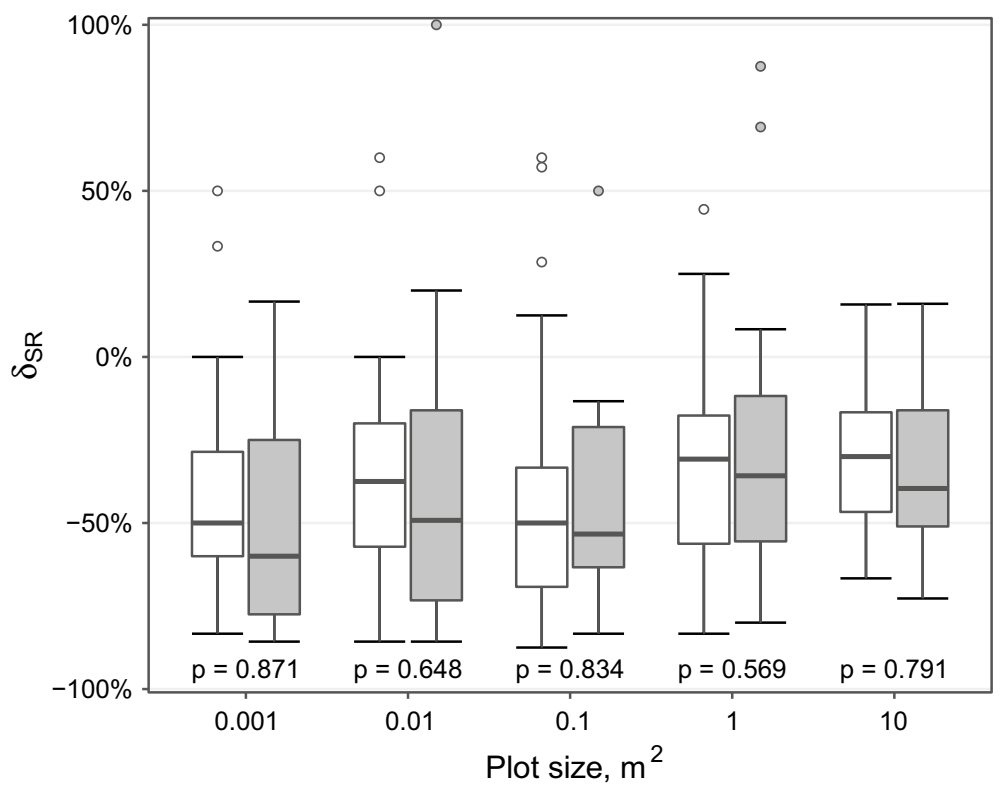

Fig. 4 Standardized difference in species richness between the high-dominance (HD) and low-dominance (LD) series of nested plots $\left(\delta_{\mathrm{SR}}, \%\right)$ illustrated for alien-dominated (white) and native-dominated (grey) subsets of series. Statistical significance between alien- and native-dominated subsets of series was tested by means of ANOVA (after Bonferroni correction)

opportunities for species with similar ecological requirements to avoid competition by growing in different places (Godsoe et al. 2015).

Finally, we found no evidence that the effect of dominance on SR and the species accumulation rate would be stronger for alien species than for native ones. This dominance effect is well known for alien species (Gerber et al. 2008; Vilà et al. 2011), but it has been less studied for native species (Hansson and Fogelfors 2000; Csergó et al. 2013). Our results are similar to those presented by Meiners et al. (2001) in their long-term observational study of abandoned agricultural fields. They found that the increasing dominance of alien and native plants during old-field succession had a similar effect on SR. Opposite conclusions were presented by Vilà and Weiner (2004), who reviewed the published data and found that alien dominant plants have a stronger impact on the community structure than native dominant plants. However, they noted that most studies focus on species that are well known for their high invasiveness and negative effects on the diversity of invaded plant communities.

In the present study, the most important dominant species which influenced SR and the rate of species accumulation with increasing area were found among both alien (Solidago gigantea and S. canadensis) and native species (Carex brizoides). It is likely that the tall height or high biomass production of these plants is responsible for their strong negative effect on biodiversity, especially through increasing competition for light (Jakobs et al. 2004; Chmura and Sierka 2007; Divíšek et al. 2018). Experimental studies also confirm that one of the most important traits of competitors is a high growth rate and high biomass production (Gaudet and Keddy 1988; Szymura and Szymura 2015). Other dominant species such as Lupinus polyphyllus (alien) and Agrostis capillaris (native) had minor impacts 
Fig. 5 Comparisons of the loglog species-area curves between the high-dominance (HD) and low-dominance (LD) series of nested plots. The power-law function was fitted to the mean species richness for each plot size across all series. The big black symbols represent mean species richness per unit area ( $c$-value), while the small grey symbols represent single values of species richness. The slopes of the lines are interpreted as the rate of species accumulation with increasing sampling area ( $z$-value). The differences in $c$ - and z-values between the HD and LD series within each $100-\mathrm{m}^{2}$ square were tested using Student's $t$-test for paired samples. Note that single points were jittered along the $\mathrm{X}$-axis to avoid overlapping (a) All nested-plot series

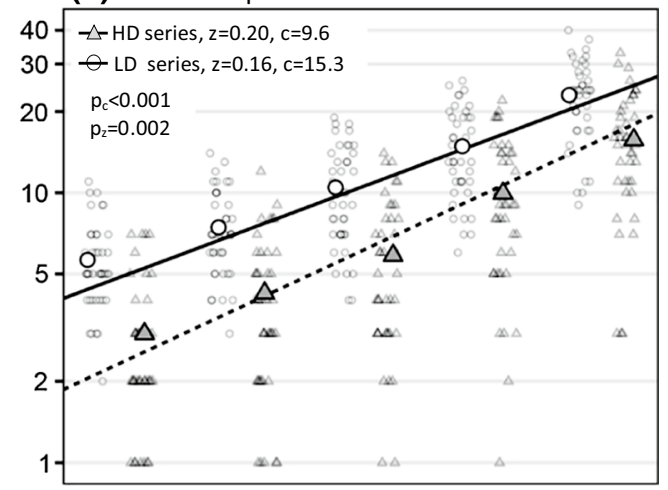

(b) Alien-dominated nested-plot series

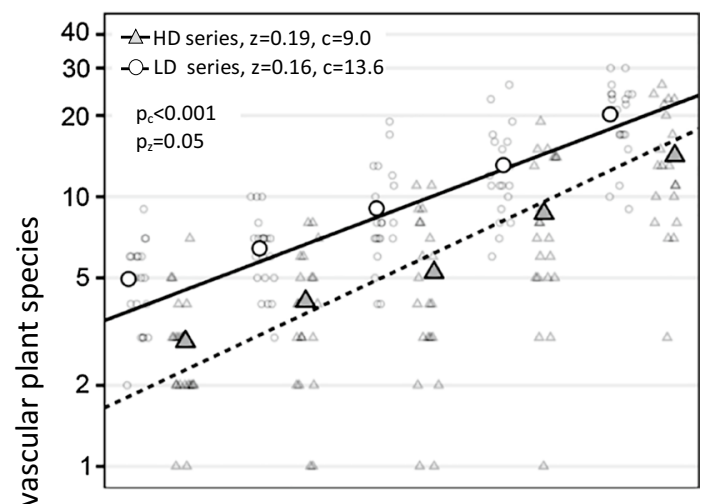

(c) Native-dominated nested-plot series

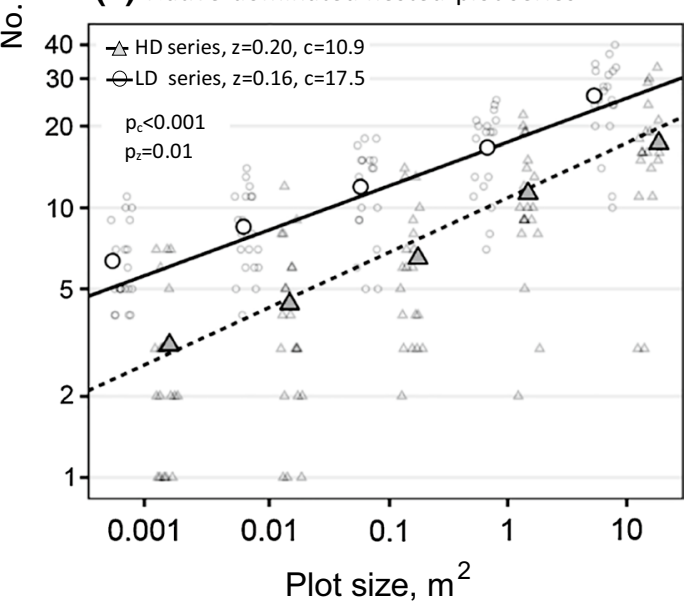

on SR and the rate of species accumulation with increasing area. The negligible effect of L. polyphyllus can be explained by its patchy growth, which allows other species to occupy empty patches (Hejda 2013), while A. capillaris is a medium-tall grass with narrow leaves and relatively sparse stands with limited shading effect. Further, A. capillaris is native to 

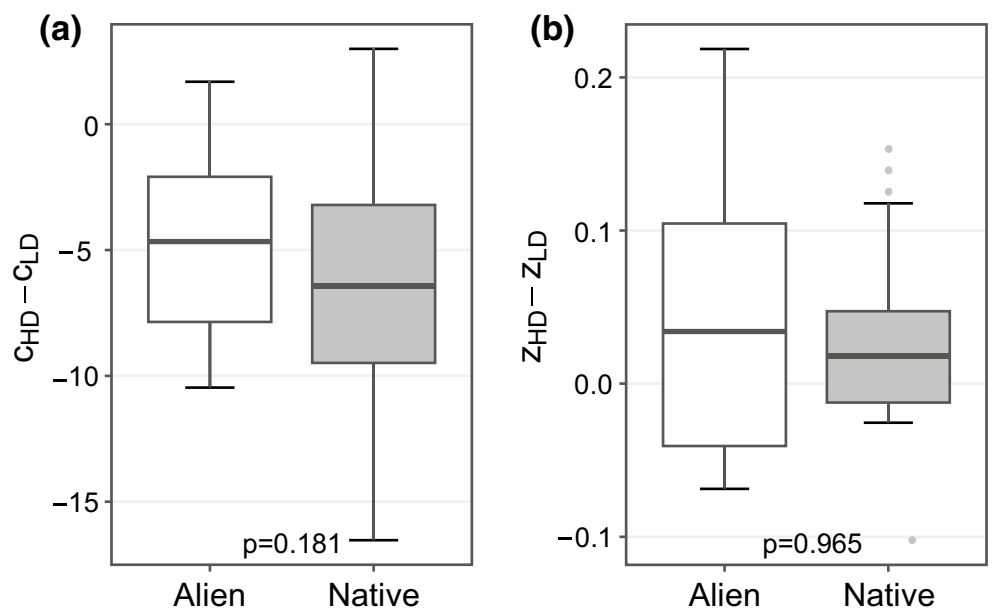

Fig. 6 A comparison of differences in the effect of species dominance on the species-area relationship between the alien-dominated and the native-dominated subsets. The effect of species dominance $\left(\mathrm{c}=\mathrm{c}_{\mathrm{HD}}-\right.$ $\mathrm{c}_{\mathrm{LD}} ; \mathrm{z}=\mathrm{z}_{\mathrm{HD}}-\mathrm{z}_{\mathrm{LD}}$ ) is measured as the difference in $c$-value (a) and $z$-value (b) of the species-area relationship between the high-dominance (HD) and low-dominance (LD) series of nested plots within each aliendominated or native-dominated subset. Statistical significance was tested by means of ANOVA

Europe but alien to Asia, Australia and North America, where it is known as a strong competitor that causes a decrease in the cover of native species (Johnston and Pickering 2001).

Although our results suggest that alien and native species have similar impacts on SR and on the rate of species accumulation with increasing area, we should note that, in general, different factors are related to the dominance of alien or native plant species. Studies on plant invasions have shown that dominance of alien species is positively correlated with several factors including landscape fragmentation (Vilà and Ibáñez 2011), disturbances (Deutschewitz et al. 2003) and propagule pressure (Lonsdale 1999), whereas increasing dominance of native plant species is often connected with changes in agricultural management (Bobbink et al. 1987; Hejcman et al. 2009). However, comparative studies of factors affecting the dominance of alien versus native species are scarce. Seabloom et al. (2015) found that the cover of alien species increased more than the cover of native species after nutrient additions, while higher native species cover was strongly connected with the cessation of grazing. More comparative studies are needed to obtain a better understanding of the phenomenon of increasing dominance of alien versus native species.

The observed negative impact of strong native competitors on biodiversity (Bobbink et al. 1987; de la Cretaz and Kelty 1999; Ervin and Wetzel 2002; Chmura and Sierka 2007; Daleo et al. 2017) has motivated a discussion on how species are classified as invasive. Some experts have proposed that problematic native species can also be classified as invasive (Alpert et al. 2000; Valery et al. 2008). Our results are consistent with this point of view, showing that native plant species capable of becoming dominant are threatening local biodiversity to a similar degree as alien species. To avoid terminological confusion, we favour the use of the term 'expansive species', which has been proposed for native species that increase in abundance following environmental changes (Richardson et al. 2000; Pyšek et al. 2004).

The decrease in SR resulting from the increased dominance of a competitively strong species is a major concern from the perspective of nature conservation. Our results suggest 
that both alien and native dominant plants can threaten fine-scale plant diversity in temperate grasslands. Plant species which are superior competitors can significantly reduce SR in grasslands regardless of whether they are alien or native. A task for nature conservation is to categorise expanding dominant plants not only based on their origin but particularly based on the severity of their species-specific effects on biodiversity. Such categorization would be more important for prioritising management efforts than the simple dichotomy between alien and native species.

Acknowledgements The work of MC and SP was supported by the Czech Science Foundation (project 14-36079G, Centre of Excellence PLADIAS).

Open Access This article is distributed under the terms of the Creative Commons Attribution 4.0 International License (http://creativecommons.org/licenses/by/4.0/), which permits unrestricted use, distribution, and reproduction in any medium, provided you give appropriate credit to the original author(s) and the source, provide a link to the Creative Commons license, and indicate if changes were made.

\section{Appendix 1}

See Table 2. 


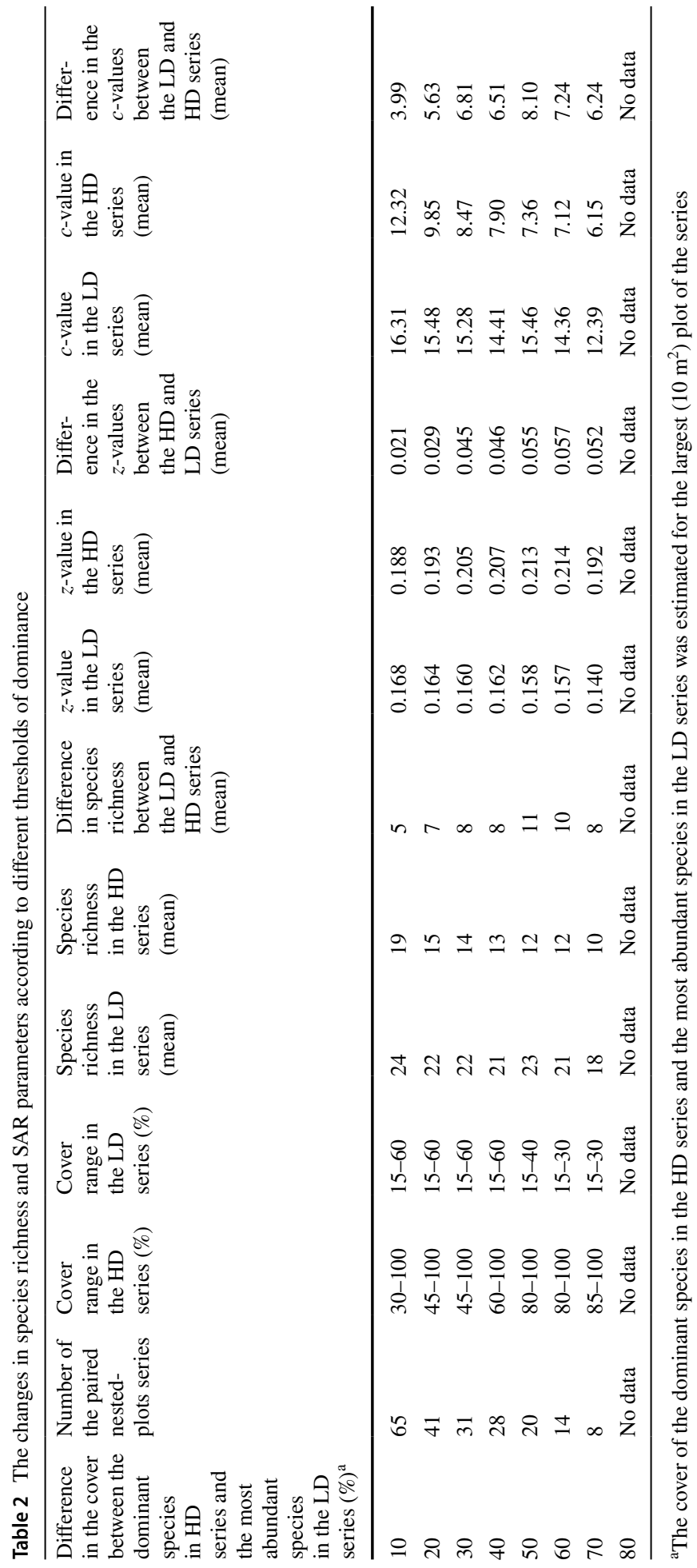




\section{References}

Alpert P, Bone E, Holzapfel C (2000) Invasiveness, invasibility and the role of environmental stress in the spread of non-native plants. PPEES 3:52-66. https://doi.org/10.1078/1433-8319-00004

Arrhenius O (1921) Species and area. J Ecol 9:95-99. https://doi.org/10.2307/2255763

Biała K, Żyszkowska M (2004) Effects of changes in grassland management on biodiversity and landscape in the Sudeten Mountains in Poland. Grassl Sci Eur 4:210-212

Bobbink R, During HJ, Schreurs J, Willems J, Zielman R (1987) Effects of selective clipping and mowing time on species diversity in chalk grassland. Folia Geobot Phytotax 22:363-376. https://doi. org/10.1007/BF02853233

Bonari G, Fajmon K, Malenovský I, Zelený D, Holuša J, Jongepierová I, Kočárek P, Uřičář J, Chytrý M (2017) Management of semi-natural grasslands benefiting both plant and insect diversity: the importance of heterogeneity and tradition. Agric Ecosyst Environ 246:243-252. https://doi.org/10.1016/j. agee.2017.06.010

Byers JE, Reichard S, Randall JM, Parker IM, Smith CS, Lonsdale WM, Atkinson IAE, Seastedt TR, Williamson M, Chornesky E, Hayes D (2002) Directing research to reduce the impacts of nonindigenous species. Conserv Biol 16:630-640. https://doi.org/10.1046/j.1523-1739.2002.01057.x

Callaway RM, Ridenour WM (2004) Novel weapons: invasive success and the evolution of increased competitive ability. Front Ecol Environ 2:436-443. https://doi.org/10.1890/1540-9295(2004)002\%5B043 6:NWISAT\%5D2.0.CO;2

Chmura D, Sierka E (2007) The invasibility of deciduous forest communities after disturbance: a case study of Carex brizoides and Impatiens parviflora invasion. For Ecol Manage 242:487-495. https://doi. org/10.1016/j.foreco.2007.01.083

Chmura D, Tokarska-Guzik B, Nowak T, Woźniak G, Bzdęga K, Koszela K, Gancarek M (2015) The influence of invasive Fallopia taxa on resident plant species in two river valleys (southern Poland). Acta Soc Bot Pol 84:23-33. https://doi.org/10.5586/asbp.2015.008

Crawley MJ, Harral JE (2001) Scale dependence in plant biodiversity. Science 291:864-868. https://doi. org/10.1126/science.291.5505.864

Csergő AM, Demeter L, Turkington R (2013) Declining diversity in abandoned grasslands of the Carpathian Mountains: do dominant species matter? PLoS ONE 8:e73533. https://doi.org/10.1371/journ al.pone.0073533

Daleo P, Alberti J, Bruschetti CM, Martinetto P, Pascual J, Iribarne O (2017) Herbivory and presence of a dominant competitor interactively affect salt marsh plant diversity. J Veg Sci 28:1178-1186. https:// doi.org/10.1111/jvs.12574

de la Cretaz AL, Kelty MJ (1999) Establishment and control of hay-scented fern: a native invasive species. Biol Invasions 1:223-236. https://doi.org/10.1023/A:1010098316832

Dengler J (2009) A flexible multi-scale approach for standardized recording of plant species richness patterns. Ecol Indic 9:1169-1178. https://doi.org/10.1016/j.ecolind.2009.02.002

Deutschewitz K, Lausch A, Kühn I, Klotz S (2003) Native and alien plant species richness in relation to spatial heterogeneity on a regional scale in Germany. Global Ecol Biogeogr 12:299-311. https:// doi.org/10.1046/j.1466-822X.2003.00025.x

Divíšek J, Chytrý M, Beckage B, Gotelli NJ, Lososová Z, Pyšek P, Molofsky J (2018) Similarity of introduced plant species to native ones facilitates naturalization, but differences enhance invasion success. Nat Commun 9:art.4631. https://doi.org/10.1038/s41467-018-06995-4

Dolnik C, Breuer M (2008) Scale dependency in the species-area relationship of plant communities. Folia Geobot 43:305-318. https://doi.org/10.1007/s12224-008-9019-4

Dostálek J, Frantík T (2012) The impact of different grazing periods in dry grasslands on the expansive grass Arrhenatherum elatius L. and on woody species. Environ Manage 49:855-861. https://doi. org/10.1007/s00267-012-9819-4

Drakare S, Lennon JJ, Hillebrand H (2006) The imprint of the geographical, evolutionary and ecological context on species-area relationships. Ecol Lett 9:215-227. https://doi.org/10.111 1/j.1461-0248.2005.00848.x

Duelli P, Obrist MK (2003) Regional biodiversity in an agricultural landscape: the contribution of seminatural habitat islands. Basic Appl Ecol 4:129-138. https://doi.org/10.1078/1439-1791-00140

Ervin GN, Wetzel RG (2002) Influence of a dominant macrophyte, Juncus effusus, on wetland plant species richness, diversity, and community composition. Oecologia 130:626-636. https://doi. org/10.1007/s00442-001-0844-X

Euro + Med (2006-2018): Euro + Med PlantBase-the information resource for Euro-Mediterranean plant diversity. http://ww2.bgbm.org/EuroPlusMed/. Accessed 2 Nov 2018 
Falcucci A, Maiorano L, Boitani L (2007) Changes in landuse/land-cover patterns in Italy and their implications for biodiversity conservation. Landsc Ecol 22:617-631. https://doi.org/10.1007/s1098 0-006-9056-4

Falińska K (1991) Plant demography in vegetation succession. Tasks Veg Sci 26:1-210

Gaudet CL, Keddy PA (1988) A comparative approach to predicting competitive ability from plant traits. Nature 334:242-243. https://doi.org/10.1038/334242a0

Gerber E, Krebs C, Murrell C, Moretti M, Rocklin R, Schaffner U (2008) Exotic invasive knotweeds (Fallopia spp.) negatively affect native plant and invertebrate assemblages in European riparian habitats. Biol Conserv 141:646-654. https://doi.org/10.1016/j.biocon.2007.12.009

Godsoe W, Murray R, Plank MJ (2015) The effect of competition on species' distributions depends on coexistence, rather than scale alone. Ecography 38:1071-1079. https://doi.org/10.1111/ecog.01134

Guilhaumon F, Mouillot D, Gimenez O (2010) mmSAR: an R-package for multimodel species-area relationship inference. Ecography 33:420-424. https://doi.org/10.1111/j.1600-0587.2010.06304.X

Hansson M, Fogelfors H (2000) Management of a semi-natural grassland; results from a 15-year-old experiment in southern Sweden. J Veg Sci 11:31-38. https://doi.org/10.2307/3236772

Házi J, Bartha S, Szentes S, Wichmann B, Penksza K (2011) Seminatural grassland management by mowing of Calamagrostis epigejos in Hungary. Plant Biosyst 145:699-707. https://doi. org/10.1080/11263504.2011.601339

Hejcman M, Češková M, Hejcmanová P, Pavlů V, Jones M (2009) Expansion of Calamagrostis villosa in sub-alpine Nardus stricta grassland: Cessation of cutting management or high nitrogen deposition? Agric Ecosyst Environ 129:91-96. https://doi.org/10.1016/j.agee.2008.07.007

Hejda M (2013) Do species differ in their ability to coexist with the dominant alien Lupinus polyphyllus? A comparison between two distinct invaded ranges and a native range. NeoBiota 17:39-55. https:// doi.org/10.3897/neobiota.17.4317

Hejda M, Pyšek P (2006) What is the impact of Impatiens glandulifera on species diversity of invaded riparian vegetation? Biol Conserv 132:143-152. https://doi.org/10.1016/j.biocon.2006.03.025

Hejda M, Pyšek P, Jarošík V (2009) Impact of invasive plants on the species richness, diversity and composition of invaded communities. J Ecol 97:393-403. https://doi.org/10.111 1/j.1365-2745.2009.01480.x

Hillebrand H, Bennett DM, Cadotte MW (2008) Consequences of dominance: a review of evenness effects on local and regional ecosystem processes. Ecology 89:1510-1520. https://doi. org/10.1890/07-1053.1

Jakobs G, Weber E, Edwards PJ (2004) Introduced plants of the invasive Solidago gigantea (Asteraceae) are larger and grow denser than conspecifics in the native range. Divers Distrib 10:11-19. https:// doi.org/10.1111/j.1472-4642.2004.00052.x

Johnston FM, Pickering CM (2001) Alien plants in the Australian Alps. Mt Res Dev 21:284-291. https:// doi.org/10.1659/0276-4741(2001)021\%5B0284:APITAA\%5D2.0.CO;2

Kącki Z, Śliwiński M (2012) The polish vegetation database: structure, resources and development. Acta Soc Bot Pol 81:75-79. https://doi.org/10.5586/asbp.2012.014

Kącki Z, Czarniecka M, Swacha G (2013) Statistical determination of diagnostic, constant and dominant species of the higher vegetation units of Poland. Monogr Bot 103:1-267. https://doi.org/10.5586/mb.2013.001

Lepš J (2004) Variability in population and community biomass in a grassland community affected by environmental productivity and diversity. Oikos 107:64-71. https://doi.org/10.111 1/j.0030-1299.2004.13023.x

Lonsdale WM (1999) Global patterns of plant invasions and the concept of invasibility. Ecology 80:1522-1536. https://doi.org/10.1890/0012-9658(1999)080\%5B1522:GPOPIA\%5D2.0.CO;2

MacDonald D, Crabtree JR, Wiesinger G, Dax T, Stamou N, Fleury P, Gutierrex Lazpita J, Gibon A (2000) Agriculture abandonment in mountain areas of Europe: environmental consequences and policy response. J Environ Manage 59:47-69. https://doi.org/10.1006/jema.1999.0335

Maskell LC, Firbank G, Thompson K, Bullock JM, Smart SM (2006) Interaction between non-native plant species and the floristic composition of common habitats. J Ecol 94:1052-1060. https://doi. org/10.1111/j.1365-2745.2006.01172.x

Meiners SJ, Pickett STA, Cadenasso ML (2001) Effects of plant invasions on the species richness of abandoned agricultural land. Ecography 24:633-644. https://doi.org/10.1111/j.1600-0587.2001.tb00525.x

Nadolna L, Żyszkowska M (2011) Characteristics of grasslands in the Polish Sudetes in view of fodder production potential and grassland protection. J Water Land Dev 15:29-40. https://doi.org/10.2478/ v10025-012-0003-2

Parker IM, Simberloff D, Lonsdale WM, Goodell K, Wonham M, Kareiva PM, Williamson MH, von Holle B, Moyle PB, Byers JE, Goldwasser L (1999) Impact: toward a framework for understanding the ecological effects of invaders. Biol Invasions 1:3-19. https://doi.org/10.1023/A:1010034312781 
Planty-Tabacchi AM, Tabacchi E, Naiman RJ, Deferrari C, Decamps H (1996) Invasibility of species-rich communities in riparian zones. Conserv Biol 10:598-607. https://doi.org/10.104 6/j.1523-1739.1996.10020598.x

Poschlod P, Bakker JP, Kahmen S (2005) Changing land use and its impact on biodiversity. Basic Appl Ecol 6:93-98. https://doi.org/10.1016/j.baae.2004.12.001

Powell KI, Chase JM, Knight TM (2013) Invasive plants have scale-dependent effects on diversity by altering species-area relationships. Science 339:316-318. https://doi.org/10.1126/science.1226817

Prévosto B, Kuiters L, Bernhardt-Römermann M, Dölle M, Schmidt W, Hoffmann M, van Uytvanck J, Bohner A, Kreiner D, Stadler J, Klotz S, Brandl R (2011) Impacts of land abandonment on vegetation: successional pathways in European habitats. Folia Geobot 46:303-325. https://doi. org/10.1007/s12224-010-9096-Z

Pyšek P, Pyšek A (1995) Invasion by Heracleum mantegazzianum in different habitats in the Czech Republic. J Veg Sci 6:711-718. https://doi.org/10.2307/3236442

Pyšek P, Richardson DM, Rejmánek M, Webster GL, Williamson M, Kirschner J (2004) Alien plants in checklists and floras: towards better communication between taxonomists and ecologists. Taxon 53:131-143. https://doi.org/10.2307/4135498

Richardson DM, Pyšek P, Rejmánek M, Barbour MG, Panetta FD, West CJ (2000) Naturalization and invasion of alien plants: concepts and definitions. Divers Distrib 6:93-107. https://doi.org/10.104 6/j.1472-4642.2000.00083.x

Rosenzweig ML (1995) Species diversity in space and time. Cambridge University Press, Cambridge. https://doi.org/10.1017/CBO9780511623387

Ruprecht E, Enyedi MZ, Szabó A, Fenesi A (2016) Biomass removal by clipping and raking vs burning for the restoration of abandoned Stipa-dominated European steppe-like grassland. Appl Veg Sci 19:78-88. https://doi.org/10.1111/avsc.12199

Seabloom EW, Borer ET, Buckley YM, Cleland EE, Davies KF, Firn J et al (2015) Plant species' origin predicts dominance and response to nutrient enrichment and herbivores in global grasslands. Nat Commun 6:1-8. https://doi.org/10.1038/ncomms8710

Szymura M, Szymura TH (2015) The dynamics of growth and flowering of invasive Solidago species. Steciana 19:143-152. https://doi.org/10.12657/steciana.019.016

Tilman D, Pacala S (1993) The maintenance of species richness in plant communities. In: Ricklefs RE, Schluter D (eds) Species diversity in ecological communities. University of Chicago Press, Chicago, pp 13-25

Tscharntke T, Klein AM, Kruess A, Steffan-Dewenter I, Thies C (2005) Landscape perspectives on agricultural intensification and biodiversity-ecosystem service management. Ecol Lett 8:857-874. https://doi.org/10.1111/j.1461-0248.2005.00782.x

Vilà M, Ibáñez I (2011) Plant invasions in the landscape. Landsc Ecol 26:461-472. https://doi. org/10.1007/s 10980-011-9585-3

Vilà M, Weiner J (2004) Are invasive plant species better competitors than native plant species? - evidence from pair-wise experiments. Oikos 105:229-238. https://doi.org/10.1111/j.0030-1299.2004.12682.x

Vilà M, Espinar JL, Hejda M, Hulme PE, Jarošík V, Maron JL, Pergl J, Schaffner U, Sun Y, Pyšek P (2011) Ecological impacts of invasive alien plants: a meta-analysis of their effects on species, communities and ecosystems. Ecol Lett 14:702-708. https://doi.org/10.1111/j.1461-0248.2011.01628.x

Walczak W (1968) Sudety. PWN, Warszawa - Kraków - Gdańsk - Łódź

Wehn S, Taugourdeau S, Johansen L, Hovstad KA (2017) Effects of abandonment on plant diversity in seminatural grasslands along soil and climate gradients. J Veg Sci 28:838-847. https://doi.org/10.1111/ jvs. 12543

Whittaker RH (1965) Dominance and diversity in land plant communities. Science 147:250-260. https:// doi.org/10.1126/science.147.3655.250

Woś A (1999) Klimat Polski. PWN, Warszawa

Young J, Watt A, Nowicki P, Alard D, Clitherow J, Henle K, Johnson R, Laczko E, McCracken D, Matouch S, Niemela J, Richards C (2005) Towards sustainable land use: identifying and managing the conflicts between human activities and biodiversity conservation in Europe. Biodivers Conserv 14:1641-1661. https://doi.org/10.1007/s10531-004-0536-z

Zehnsdorf A, Hussner A, Eismann F, Rönicke H, Melzer A (2015) Management options of invasive Elodea nuttallii and Elodea canadensis. Limnologica 51:110-117. https://doi.org/10.1016/j.limno.2014.12.010

Publisher's Note Springer Nature remains neutral with regard to jurisdictional claims in published maps and institutional affiliations. 